\title{
Correction to: The forces of attraction: How security interests shape membership in economic institutions
}

\author{
Christina L. Davis ${ }^{1}$ (D) ${\text { Tyler } \text { Pratt }^{2}}^{2}$ \\ Published online: 8 March 2021 \\ C) Springer Science+Business Media, LLC, part of Springer Nature 2021
}

\section{Correction to: The Review of International Organizations https://doi.org/10.1007/s11558-020-09395-w}

The esm files in the original article need to be updated.

The original article has been corrected.

Publisher's note Springer Nature remains neutral with regard to jurisdictional claims in published maps and institutional affiliations.

The online version of the original article can be found at https://doi.org/10.1007/s11558-020-09395-W

Christina L. Davis

cldavis@harvard.edu

Tyler Pratt

tyler.pratt@yale.edu

1 Weatherhead Center for International Affairs, Harvard University, 1737 Cambridge Street, Cambridge, MA 02138, USA

2 Yale University, New Haven, CT 06520, USA 